Article

\title{
Geographic and Socioeconomic Influence on Knowledge and Practices Related to Antimicrobial Resistance among Smallholder Pig Farmers in Uganda
}

\author{
Sandra Nohrborg ${ }^{1}\left(\mathbb{D}\right.$, Michel Mainack Dione ${ }^{2} \mathbb{D}$, Amia Christine Winfred ${ }^{3}$, Louis Okello ${ }^{4}$, Barbara Wieland ${ }^{5,6}$ \\ and Ulf Magnusson $1, *$ (D)
}

check for

updates

Citation: Nohrborg, S.; Dione, M.M.; Winfred, A.C.; Okello, L.; Wieland, B.; Magnusson, U. Geographic and Socioeconomic Influence on Knowledge and Practices Related to Antimicrobial Resistance among Smallholder Pig Farmers in Uganda. Antibiotics 2022, 11, 251. https:// doi.org/10.3390/antibiotics11020251

Academic Editor: Albert Figueras

Received: 18 January 2022

Accepted: 10 February 2022

Published: 15 February 2022

Publisher's Note: MDPI stays neutral with regard to jurisdictional claims in published maps and institutional affiliations.

Copyright: (C) 2022 by the authors. Licensee MDPI, Basel, Switzerland. This article is an open access article distributed under the terms and conditions of the Creative Commons Attribution (CC BY) license (https:// creativecommons.org/licenses/by/ $4.0 /)$.
1 Department of Clinical Sciences, Swedish University of Agricultural Sciences, SE-750 07 Uppsala, Sweden; sandra.nohrborg@slu.se

2 Animal and Human Health Program, International Livestock Research Institute, Ouakam, Dakar BP 24265, Senegal; m.dione@cgiar.org

3 Mott MacDonald Uganda Limited, Kampala 10101, Uganda; winfred.amia@mottmac.com

4 Independent Researcher, Kampala 10101, Uganda; louisomoya@gmail.com

5 Institute of Virology and Immunology, CH-3147 Mittelhausern, Switzerland; barbara.wieland@ivi.admin.ch

6 Department of Infectious Diseases and Pathobiology, Vetsuisse Faculty, University of Bern, CH-3012 Bern, Switzerland

* Correspondence: ulf.magnusson@slu.se

\begin{abstract}
To mitigate the development of antimicrobial resistance (AMR), antibiotic use (ABU) in the livestock sector needs to be reduced. In low- and middle-income countries, regulations have shown to be less successful in reducing ABU. Here, a bottom-up approach can complement legal frameworks, which requires an understanding of the drivers for ABU. In this study, we investigated the influence of geographic and socioeconomic settings on determinants for ABU among pig farmers in Uganda. The data were collected through a questionnaire in two districts, Lira and Mukono, and comparative statistical analyses were performed. Farmers in Lira had less access to animal health services, applied disease prevention measures less and used antibiotics more. In Mukono, it was more common to consult a veterinarian in response to disease, while in Lira it was more common to consult an animal health worker. There was no difference in how many farmers followed treatment instructions from a veterinarian, but it was more common in Lira to follow instructions from pharmacies. The findings support the need for locally tailored AMR-reducing interventions to complement regulations. To accomplish this tailoring, systematic collection of knowledge of farm structures, farm practices and access to animal health services and veterinary drugs is necessary.
\end{abstract}

Keywords: antimicrobial use; antimicrobial resistance; smallholders; pig farming; livestock; farm practices; knowledge; access

\section{Introduction}

Antimicrobials have been, and still are, invaluable tools in treating bacterial diseases in both humans and animals. Therefore, the development of antimicrobial resistance (AMR) is a major threat to public and animal health [1,2]. Besides the direct health consequences, it may also threaten food security and livelihoods, especially in low- and middle-income countries (LMICs) [3].

Even though AMR is a naturally occurring mechanism in bacteria [4-6], the widespread use of antibiotics in humans and livestock has accelerated this development. Consequently, AMR has reached alarming levels in many parts of the world [7-10]. Thus, a future without access to effective antibiotic treatment might be a reality if this development is not mitigated. Since bacteria can spread between animals and humans [11], either directly or indirectly (e.g., through food products or the environment), AMR is a true 'One Health' 
issue that needs to be handled at the global level together by the human and livestock sectors, including the biosciences and social sciences, in an interdisciplinary manner [12].

It has been estimated that the global antibiotic use in the livestock sector exceeds their use in humans [8]. Therefore, it is essential to stop over- and misuse of antibiotics in the livestock sector. Antibiotics in livestock production are used not only for treatment of disease but also in more imprudent ways, such as for disease prevention (prophylaxis) and growth promotion $[1,13]$. Other problems are the use of antibiotics without proper diagnostics or lack of access to the best-suited antibiotics. Extensive use of antibiotics is also facilitated by weak legislation and guidelines on antibiotic sales and use, and in some settings insufficient enforcement of, and compliance with, such regulations [13-15].

Studies have indicated that AMR levels in bacteria isolated from livestock have increased in LMICs since the beginning of the millennium, with the largest increase in poultry and pig production [10]. However, the level of AMR differs between regions, and so far sub-Saharan Africa (SSA) seems to have a lower level of AMR than, for example, Southeast Asia. Current and emerging hotspots for AMR bacteria in livestock have, however, been identified in Egypt, South Africa and Kenya, indicating that the problem is existent and on the rise in Africa as well [10]. In Uganda, from which the data presented in this paper are collected, studies have shown varying frequency of AMR bacteria, including multi-drug resistant ones, in both human and animal samples [13,16-22]. Neighboring countries, such as Kenya and Tanzania, seem to share a similar situation, according to several studies [23-25]. However, the overall AMR burden in SSA is difficult to evaluate because of the limited number of studies conducted in this region compared to other LMIC regions, such as South and Southeast Asia [10].

In LMICs, such as Uganda, where small-scale production is still dominant and with a generally low awareness about AMR among the farmers, legislation and other regulations have been shown to be less successful in reducing antibiotic use [14,15]. Limited resources to enforce the regulations [13] and/or poor infrastructure in rural areas can make compliance control difficult. In addition, poor access to professional animal health services and insufficient laboratory capacity can compromise the farmers' abilities to follow regulations and to perform the 'best practices' from an AMR perspective [26].

Therefore, a more bottom-up approach showing the farmers how to reduce the need for antibiotics and use them in a medically rational way may be a promising approach to complement existing legal frameworks. However, this requires an understanding of the drivers for antibiotic use by the farmers. By identifying and understanding these drivers, interventions can be tailored to fit different socioeconomic circumstances $[27,28]$. Thus, farmers' access to veterinary advice and drugs, as well as their knowledge and practices related to AMR, are critical parameters to evaluate.

The overall objective of this study was to increase our understanding about how to improve the tailoring of interventions aimed to refine smallholders' use of antimicrobials in livestock in LMICs. Specifically, we wanted to investigate the possible influence of geographic and socioeconomic settings on some major determinants for antibiotic use among pig farmers within the same regulatory framework. Thus, we designed a study targeting two districts in Uganda with different production characteristics and compared the smallholder pig farmers' access to animal health services and veterinary drugs, and their practices and knowledge related to antibiotics and AMR. In short, we found that legal regulations alone are not sufficient to control antimicrobial use in livestock.

\section{Results}

\subsection{Background Information}

The demographics and socioeconomic characteristics of the farmers, farm characteristics, feeding and manure handling routines and pig disease occurrence in the two districts are presented in detail in supplementary Tables S1-S4. These data support the already perceived view of Lira being a more rural district where people to a higher degree depend on livestock than in peri-urban Mukono. For example, livestock contributed more to the 
household income in Lira than in Mukono and it was more common in Mukono to have the main income source outside the farm. We also identified signs of a more advanced livestock production in Mukono, with hired workers to a larger extent, more pigs per farm and keeping the pigs housed instead of tethered. Selling live pigs and feeding the pigs with commercial or pre-mixed feed or restaurant/household waste was also more common in Mukono, which might indicate better market access in the district, being more urban than Lira, and given its proximity to the capital Kampala. In Lira, on the other hand, scavenging and pasture grazing were common feeding practices, further reflecting the more rural and traditional farm conditions in the district. Also, farmers in Mukono to a larger extent made use of the pig manure as a fertilizer while farmers in Lira more often discarded or left the manure in open air. Farmers in Lira were also challenged with higher disease rates among their pigs.

\subsection{Access to Animal Health Services and Veterinary Drugs}

The data on access to, and use of, animal health services and veterinary drugs at the investigated farms are presented in Table 1.

Table 1. Comparison of access to animal health services and veterinary drugs in smallholder pig farms in Lira and Mukono districts, Uganda.

\begin{tabular}{|c|c|c|c|c|}
\hline Item & Category & Lira & Mukono & $p$-Value \\
\hline & & $\%(n)$ & $\%(n)$ & \\
\hline $\begin{array}{c}\text { Does the farm have access to } \\
\text { professional animal } \\
\text { health services? }^{1}\end{array}$ & Yes & $59.4(136)$ & $94.0(220)$ & 0.000 \\
\hline \multirow[t]{4}{*}{ 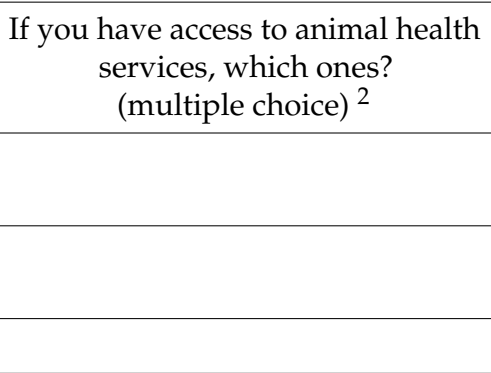 } & State or government & $3.7(5)$ & $1.4(3)$ & $\mathrm{n} / \mathrm{a}$ \\
\hline & $\begin{array}{l}\text { Private full time animal } \\
\text { health worker }\end{array}$ & $76.5(104)$ & $52.7(116)$ & 0.000 \\
\hline & $\begin{array}{l}\text { Both state/government } \\
\text { and private }\end{array}$ & $14.7(20)$ & $30.0(65)$ & 0.001 \\
\hline & Don't know & $11.8(16)$ & $16.8(37)$ & 0.193 \\
\hline $\begin{array}{l}\text { If you have access to animal health } \\
\text { services, do the animal services } \\
\text { include laboratory testing? }\end{array}$ & Yes & $0.7(1)$ & $1.8(4)$ & $\mathrm{n} / \mathrm{a}$ \\
\hline $\begin{array}{l}\text { Is the farm involved in a regular } \\
\text { animal health service program } \\
\text { (all species), e.g., } \\
\text { vaccination campaign? }^{1}\end{array}$ & Yes & $45.0(103)$ & $17.5(40)$ & 0.000 \\
\hline $\begin{array}{l}\text { Do you have access to } \\
\text { pharmaceuticals/ } \\
\text { veterinary drugs? }{ }^{1}\end{array}$ & Yes & $66.8(153)$ & $67.9(159)$ & 0.794 \\
\hline
\end{tabular}

\footnotetext{
${ }^{1}$ Lira $n=229$ Mukono $n=234,{ }^{2}$ Lira $n=136$ Mukono $n=220 . \mathrm{n} / \mathrm{a}=$ not applicable, comparative statistic analysis
} could not be performed.

The access to professional animal health services differed significantly between the districts $(p=0.000)$, where $59 \%$ of the farms in Lira and $94 \%$ of the farms in Mukono had access to such services. Of those who had access to animal health services, the most common animal health service that could be accessed in both districts was a private fulltime animal health worker, but the proportion was higher in Lira $(p=0.000)$. Access to both private and state or governmental animal health services was in turn more common in Mukono than in Lira $(p=0.001)$. In both districts, it was almost non-existent that the animal health services included laboratory testing. Further, it was more common that the farms 
in Lira were involved in a regular animal health service program, such as a vaccination program, compared to the farms in Mukono $(p=0.000)$.

No difference between the districts regarding access to pharmaceuticals or veterinary drugs could be shown, with about two-thirds of the farms in each district having such access.

\subsection{Disease Prevention} Table 2

The data on disease prevention measures at the investigated farms are presented in

Table 2. Comparison of disease prevention practices in smallholder pig farms in Lira and Mukono districts, Uganda.

\begin{tabular}{|c|c|c|c|c|}
\hline Item & Category & Lira & Mukono & $p$-Value \\
\hline & & $\%(n)$ & $\%(n)$ & \\
\hline $\begin{array}{c}\text { Do you have any } \\
\text { particular means to } \\
\text { protect animals from } \\
\text { disease (all species)? }\end{array}$ & Yes & $48.0(110)$ & $73.1(171)$ & 0.000 \\
\hline \multirow[t]{4}{*}{$\begin{array}{l}\text { If yes, how (for pigs)? } \\
\text { (multiple choice) }^{2}\end{array}$} & Fencing & $14.6(15)$ & $23.7(40)$ & 0.070 \\
\hline & $\begin{array}{l}\text { Not mixing with other } \\
\text { herd/flock }\end{array}$ & $32.0(33)$ & $40.2(68)$ & 0.175 \\
\hline & Special feed & $3.9(4)$ & $1.8(3)$ & $\mathrm{n} / \mathrm{a}$ \\
\hline & $\begin{array}{l}\text { Veterinary drugs (incl. } \\
\text { vaccines) }\end{array}$ & $55.3(57)$ & $63.9(108)$ & 0.161 \\
\hline
\end{tabular}

${ }^{1}$ Lira $n=229$ Mukono $n=234,{ }^{2}$ Lira $n=103$ Mukono $n=169$. $\mathrm{n} / \mathrm{a}=$ not applicable, comparative statistic analysis could not be performed.

In Mukono, $73 \%$ of the respondents said that they had particular means to protect their animals from disease (all species included), which was more common than in Lira $(p=0.000)$. In both districts, the most common disease prevention measures for pigs were the use of veterinary drugs (including use of vaccines) and not mixing the pigs with other herds or flocks of animals.

\subsection{Response to Disease}

The data on responses to pig disease problems at the investigated farms are presented in Table 3.

In Lira, the most common responses to disease issues in pigs were to do nothing (35\% of the respondents) or to consult a community animal health worker $(34 \%)$. Both these proportions were higher in Lira than in Mukono $(p=0.000$ and $p=0.000)$. However, consulting a private veterinarian was more common in Mukono than in Lira $(p=0.000)$. In both districts, it was less common than previously mentioned responses to consult a governmental veterinarian or to use medicine from a veterinary drug store. 
Table 3. Comparison of pig disease response in smallholder pig farms in Lira $(n=229)$ and Mukono $(n=234)$ districts, Uganda.

\begin{tabular}{ccccc}
\hline Item & Category & Lira & Mukono & $p$-Value \\
\hline $\begin{array}{c}\text { What do you do in } \\
\text { response to disease } \\
\text { problems (in pigs)? } \\
\text { (multiple choice) }\end{array}$ & Use traditional medicine & $0.9(2)$ & $0.9(2)$ & $\mathrm{n} / \mathrm{a}$ \\
\hline & $\begin{array}{c}\text { Use medicine from } \\
\text { veterinary drug store }\end{array}$ & $4.4(10)$ & $6.0(14)$ & 0.433 \\
\hline $\begin{array}{c}\text { Consult community } \\
\text { animal health worker }\end{array}$ & $34.1(78)$ & $10.0(23)$ & 0.000 \\
\hline $\begin{array}{c}\text { Consult private } \\
\text { veterinarian }\end{array}$ & $24.9(57)$ & $65.4(153)$ & 0.000 \\
\hline & $\begin{array}{c}\text { Consult governmental } \\
\text { veterinarian }\end{array}$ & $2.6(6)$ & $6.0(14)$ & $\mathrm{n} / \mathrm{a}$ \\
\hline & $\begin{array}{c}\text { Veterinarian applied/left } \\
\text { drugs }\end{array}$ & $0.9(2)$ & $0.4(1)$ & $\mathrm{n} / \mathrm{a}$ \\
\hline & I do nothing & $35.4(81)$ & $17.9(42)$ & 0.000 \\
\hline
\end{tabular}

$\mathrm{n} / \mathrm{a}=$ not applicable, comparative statistic analysis could not be performed.

\subsection{Veterinary Drug Use Routines}

The data on routines regarding veterinary drug use at the investigated farms are presented in Table 4.

Table 4. Comparison of routines when using veterinary drugs in smallholder pig farms in Lira $(n=153)$ and Mukono $(n=159)$ districts, Uganda.

\begin{tabular}{|c|c|c|c|c|}
\hline Item & Category & Lira & Mukono & $p$-Value \\
\hline & & $\%(n)$ & $\%(n)$ & \\
\hline $\begin{array}{c}\text { If you have access to } \\
\text { veterinary drugs, do you } \\
\text { get advice on how to use } \\
\text { them? }\end{array}$ & Yes & 73.9 (113) & $78.0(124)$ & 0.393 \\
\hline \multirow{9}{*}{$\begin{array}{l}\text { When using veterinary } \\
\text { drugs, whose instructions } \\
\text { (kind, dose, length of } \\
\text { treatment) do you follow? } \\
\quad \text { (multiple choice) }\end{array}$} & The veterinarian's & $49.0(75)$ & $55.4(88)$ & 0.263 \\
\hline & $\begin{array}{l}\text { The animal health } \\
\text { worker's }\end{array}$ & $5.9(9)$ & $15.7(25)$ & 0.0053 \\
\hline & The pharmacy's & $43.8(67)$ & $25.2(40)$ & 0.0005 \\
\hline & Other farmer's & $2.6(4)$ & $7.6(12)$ & $\mathrm{n} / \mathrm{a}$ \\
\hline & My own judgement & $5.2(8)$ & $10.7(17)$ & $\mathrm{n} / \mathrm{a}$ \\
\hline & Other & $0.7(1)$ & $0.6(1)$ & $\mathrm{n} / \mathrm{a}$ \\
\hline & $\begin{array}{l}\text { I don't get any } \\
\text { instructions }\end{array}$ & $3.9(6)$ & $0(0)$ & $\mathrm{n} / \mathrm{a}$ \\
\hline & $\begin{array}{c}\text { I don't use veterinary } \\
\text { drugs }\end{array}$ & $0.7(1)$ & $1.9(3)$ & $\mathrm{n} / \mathrm{a}$ \\
\hline & Don't know & $3.3(5)$ & $15.1(24)$ & 0.0003 \\
\hline
\end{tabular}

$\mathrm{n} / \mathrm{a}=$ not applicable, comparative statistic analysis could not be performed. 
Among those who had access to pharmaceuticals or veterinary drugs, there was no detectable difference between the districts in how many followed treatment instructions from a veterinarian (about half of the respondents in both districts). However, following instructions from an animal health worker was more common in Mukono than in Lira $(p=0.0053)$, and, in contrast, following instructions from pharmacies was more common in Lira than in Mukono $(p=0.0005)$.

\subsection{Antibiotic Use}

The data on antibiotic use at the investigated farms are presented in Table 5.

Table 5. Comparison of self-reported antibiotic use in pigs in smallholder pig farms in Lira and Mukono districts, Uganda.

\begin{tabular}{|c|c|c|c|}
\hline Item & Lira & Mukono & $p$-Value \\
\hline & $\%(n)$ & $\%(n)$ & \\
\hline $\begin{array}{l}\text { Farmers that used at least one } \\
\text { antibiotic in pigs the past } 4 \text { weeks }\end{array}$ & $17.9(41)$ & 7.7 (18) & 0.001 \\
\hline $\begin{array}{l}\text { Farmers that had an antibiotic as the } \\
\text { most commonly used drug in pigs the } \\
\text { past } 4 \text { weeks }{ }^{2}\end{array}$ & $18.8(16)$ & $11.8(9)$ & 0.222 \\
\hline
\end{tabular}

Regarding antibiotic use in pigs during the four-week period prior to the study, a higher proportion of farmers in Lira had used antibiotics compared to farmers in Mukono $(p=0.001)$, with almost one in five in Lira and almost one in ten in Mukono. However, no significant difference could be found when it came to the proportion of farmers that had assigned an antibiotic as their most commonly used drug during this four-week period.

\subsection{Effect and Handling of Veterinary Drugs}

The data on effect and handling of veterinary drugs at the investigated farms are presented in Table 6.

Table 6. Comparison of self-reported effect and handling of veterinary drugs in smallholder pig farms in Lira $(n=229)$ and Mukono $(n=234)$ districts, Uganda.

\begin{tabular}{|c|c|c|c|c|}
\hline Item & Category & Lira & Mukono & $p$-Value \\
\hline & & $\%(n)$ & $\%(n)$ & \\
\hline $\begin{array}{c}\text { Have you experienced } \\
\text { situations where drugs } \\
\text { did not work (all } \\
\text { species)? }\end{array}$ & $\begin{array}{l}\text { Yes (frequently or } \\
\text { sometimes) }\end{array}$ & $21.0(48)$ & $26.1(61)$ & 0.195 \\
\hline \multirow[t]{6}{*}{$\begin{array}{l}\text { What do you usually do } \\
\text { with expired veterinary } \\
\text { drugs? }\end{array}$} & Dispose of & 45.9 (105) & $37.6(88)$ & 0.072 \\
\hline & Return to pharmacy & $0(0)$ & $0.9(2)$ & $\mathrm{n} / \mathrm{a}$ \\
\hline & Give to other farmer & $0(0)$ & $0.4(1)$ & $\mathrm{n} / \mathrm{a}$ \\
\hline & $\begin{array}{c}\text { Use for intended } \\
\text { treatment }\end{array}$ & $0(0)$ & $3.9(9)$ & $\mathrm{n} / \mathrm{a}$ \\
\hline & Nothing & $9.2(21)$ & $14.5(34)$ & 0.075 \\
\hline & $\begin{array}{l}\text { Never experienced } \\
\text { expired drugs }\end{array}$ & $45.0(103)$ & 42.7 (100) & 0.627 \\
\hline
\end{tabular}

$\mathrm{n} / \mathrm{a}=$ not applicable, comparative statistic analysis could not be performed. 
It was about equally common in both districts that respondents had experienced that drugs did not work. Expired veterinary drugs were most commonly disposed of in Lira, as well as in Mukono. To return expired drugs to a pharmacy, give to another farmer or to use for the intended treatment did not occur on the farms in Lira and was almost non-existent in Mukono. Notable also was that almost half of the respondents in both districts said that they never had experienced expired drugs.

\subsection{Knowledge about Vaccines and Antibiotics}

The data on the respondents' knowledge about what vaccines and antibiotics do are presented in Table 7.

Table 7. Comparison of knowledge about vaccines and antibiotics among respondents at smallholder pig farms in Lira $(n=229)$ and Mukono $(n=234)$ districts, Uganda.

\begin{tabular}{|c|c|c|c|c|}
\hline Item & Category & Lira & Mukono & $p$-Value \\
\hline & & $\%(n)$ & $\%(n)$ & \\
\hline \multirow[t]{4}{*}{$\begin{array}{c}\text { What does } \\
\text { vaccination do? } \\
\text { (multiple choice) }\end{array}$} & $\begin{array}{l}\text { Cure sick } \\
\text { animals }\end{array}$ & $4.4(10)$ & $3.4(8)$ & $\mathrm{n} / \mathrm{a}$ \\
\hline & $\begin{array}{l}\text { Prevent animals } \\
\text { from becoming } \\
\text { sick }\end{array}$ & $81.2(186)$ & $89.7(210)$ & 0.0092 \\
\hline & $\begin{array}{c}\text { Cure sick } \\
\text { animals and } \\
\text { prevent animals } \\
\text { from becoming } \\
\text { sick }\end{array}$ & $14.4(33)$ & $6.8(16)$ & 0.0081 \\
\hline & Fattening & $1.3(3)$ & $0(0)$ & $\mathrm{n} / \mathrm{a}$ \\
\hline \multirow[t]{4}{*}{$\begin{array}{c}\text { What do } \\
\text { antibiotics do? } \\
\text { (multiple choice) }\end{array}$} & $\begin{array}{l}\text { Cure sick } \\
\text { animals }\end{array}$ & 89.1 (193) & $59.4(138)$ & 0.000 \\
\hline & $\begin{array}{l}\text { Prevent animals } \\
\text { from becoming } \\
\text { sick }\end{array}$ & $13.1(25)$ & $3.0(6)$ & 0.0003 \\
\hline & $\begin{array}{c}\text { Cure sick } \\
\text { animals and } \\
\text { prevent animals } \\
\text { from becoming } \\
\text { sick }\end{array}$ & $12.7(34)$ & $37.6(89)$ & 0.000 \\
\hline & Fattening & $3.1(7)$ & $5.1(12)$ & $\mathrm{n} / \mathrm{a}$ \\
\hline
\end{tabular}

$\mathrm{n} / \mathrm{a}=$ not applicable, comparative statistic analysis could not be performed.

The belief that vaccinations prevent animals from becoming sick was clearly the most common in both districts. However, there was a significant difference between the districts, where this proportion was higher in Mukono than in Lira. There was also a higher proportion of respondents in Lira than in Mukono that believed that vaccinations both cure and prevent animals from becoming sick.

Regarding the question about what antibiotics do, the proportion of respondents that believed that antibiotics cure sick animals was higher in Lira than in Mukono. The same was true for the proportion of respondents that believed that antibiotics prevent animals from becoming sick. However, the proportion of respondents that believed that antibiotics both cure sick animals and prevent them from becoming sick was higher in Mukono than in Lira. Further, in both districts, the proportions of respondents that believed that antibiotics are used for fattening were low. 


\section{Discussion}

Our survey data highlight important differences between the districts, where farmers in Lira, the more rural of the two districts, were challenged with higher disease rates among their pigs, applied fewer biosecurity measures, had lower access to professional animal health services and used antibiotics more frequently with the instructions on veterinary drug use obtained more often from pharmacies than in Mukono.

From a disease, antibiotic use and AMR development perspective, several of the analyzed farm characteristics can play important roles, such as number of pigs kept, housing system, number of animal species kept, use of hired workers and selling of live animals. Differences in such farm characteristics and socioeconomic factors between the investigated districts result in different challenges to reduce antibiotic use and imply the need for tailored interventions to be successful in mitigating the emergence of AMR at farm level.

The socioeconomic preconditions and farm characteristics transcend into the level of disease prevention where farmers in the more peri-urban district Mukono to a higher degree had particular means to protect their animals from disease compared to Lira (73\% versus $48 \%$ ). The reasons for this difference can only be speculated, and a mix of several factors is presumable in accordance with previous research. A study among Ugandan smallholder pig farmers in high-poverty districts highlighted that constraints to animal health were lack of knowledge on husbandry practices and management, poor access to veterinary services, poor hygiene and lack of feed/poor feed quality [29]. Another study, on knowledge, attitudes and practices regarding African Swine Fever (ASF) among smallholder pig farmers in rural Uganda, showed that hurdles for implementing further control measures were lack of knowledge, lack of capital and income, cultural taboo, lack of control of animal movements and lack of regulation enforcement [30]. Worth noting is that in our study we found no differences between the districts among which disease prevention measures were taken. Also, and perhaps worrisome from an AMR perspective, the most common disease prevention measure in both districts was the prophylactic use of veterinary drugs.

One area that closely relates to the possible spread of pathogens and AMR bacteria is the handling of the manure. Discarding it in the environment, leaving it in open air or using it untreated as fertilizer can lead to the spread of pathogens via the environment or food products later consumed by humans or other animals [31,32]. Hence, risk of the spread of disease and AMR through manure was present in both districts, even though the manure handling routines differed. Further, doing nothing to take care of the manure increases the risk for infections among the animals at the farm. It is also worth highlighting that the choices to do nothing with the manure, discard it into the environment or to leave it in open air are to be seen as a waste of resources since, if treated correctly, using it as a fertilizer may enhance crop yields [33,34].

In Lira, disease rates among the pigs, both in long- and short-term, were higher than in Mukono for both respiratory and intestinal diseases as well as sudden death. There are several possible reasons for this, but our results highlight lower access to professional animal health services and lower level of disease prevention as two likely contributors. Regardless of the reasons, our results suggest that the risk for AMR development due to high disease pressure, and subsequent high antibiotic use (rational or irrational), is to be considered more pronounced in Lira than in Mukono. The good access to veterinary drugs further strengthens this reasoning.

Besides affecting the disease rates negatively (e.g., less advice on disease prevention, not getting treatment started in time), the lower access to professional animal health services in Lira reduces the possibilities to handle disease correctly, increasing the risk of inappropriate antibiotic use. However, difficulties in making a correct diagnosis in case of disease exist in both districts, since laboratory testing was practically never included in the animal health services offered. Without a correct diagnosis, there is an obvious risk of inappropriate antibiotic use, which in this regard increases the risk of AMR development in 
both districts, independently of the access to animal health services. It has previously been shown that, due to the lack of laboratory services, animal health service personnel in these districts often recommend broad-spectrum antibiotics like oxytetracycline to farmers [35], which are known to be prone to induce resistance [36,37].

The difference in access to animal health services is further reflected in the farmers responses to pig disease, where farmers in Lira to a larger extent either did nothing or consulted a community animal health worker, while more farmers in Mukono consulted a private veterinarian. The fact that private veterinarians have higher qualifications than community animal health workers suggests that farmers in Mukono to a larger extent get better quality advice when their pigs are sick, which should increase the chance of handling the disease correctly. However, as in many other countries antibiotics can constitute an important source of income for veterinarians, one should therefore be aware that there might be economic incentives for veterinary practitioners to recommend antibiotic treatment to farmers, increasing the risk for over- and misuse [38]. Regarding the income for veterinarians from sales of pharmaceuticals, Dione et al. [35] found antibiotics to be the most profitable drug category in both Lira and Mukono. Favorably, from an AMR perspective, the proportions of farmers that used veterinary drugs in response to disease problems without prior consultation from a professional animal health worker were low in both districts. Besides access to animal health services, how a farmer responds to disease among his/her pigs might obviously also have other reasons, such as economic reasons, cultural reasons or lack of knowledge regarding the disease prevention measures described above.

Based on the above discussion on access to animal health services, it was unexpected that there was no detectable difference between the districts in how many farmers followed treatment instructions from a veterinarian when using veterinary drugs (about half of the famers in both districts). However, in Lira it was almost as common to follow instructions from the pharmacy, whereas this was less the case in Mukono. If the qualification of the person working in the pharmacy is low and the pharmacies' instructions are followed to a large extent, the risk for non-rational antibiotic use is presumably elevated compared to following instructions from a trained animal health professional.

Even though no difference in access to veterinary drugs was detected between the districts, there was a higher use of antibiotics in pigs in Lira than in Mukono during the four-week period prior to the study, which is to be seen as a risk marker for AMR development. Possibly this is a consequence of the higher disease rates, both long- and short-term, on the farms in Lira compared to Mukono, discussed above. It might also relate to access to, and use of, animal health services, and whose treatment instructions are followed.

Interestingly, despite higher disease rates and more frequent antibiotic use as well as following instructions from pharmacies to a larger extent in Lira than in Mukono, there was no detectable difference in how many farmers had experienced situations where drugs did not work as expected. However, this question deals with drugs in general, and not particularly antibiotics, and also for all animal species at the farm.

A majority of respondents in both districts believed that vaccination prevents disease, which indicates that knowledge levels are good about vaccination in both districts, even though the proportion was larger in Mukono. However, it was more common among the respondents in Lira to believe that vaccination both cures and prevents disease, which might suggest that there are knowledge gaps to be filled.

When it came to knowledge about antibiotics, it was first of all promising from an AMR perspective that the belief that antibiotics are used for fattening was low in both districts. However, some knowledge gaps were also revealed. In Lira, a higher proportion of the respondents than in Mukono believed that antibiotics cure but do not prevent disease, but a higher proportion also believed that antibiotics prevent but do not cure disease (see Table 7). In Mukono, on the other hand, a larger proportion believed that antibiotics both cure and prevent disease. Obviously, it is reasonable to argue that a belief that antibiotics 
prevent disease increases the risk of using antibiotics for disease prevention, especially if access to antibiotics is good and the knowledge about the risks of AMR is low. As shown above, the most common disease prevention measure in both districts was the use of veterinary drugs, which might be regarded as a red flag, even though we cannot, from this study, say how much of these drugs were antibiotics.

As for all survey studies based on self-reporting, there are some inherent limitations in the precision of this study. These limitations may, for instance, include recall-bias about episodes weeks or months ago. The reliability of some of the data would have been improved by recording observations as well. However, given the design of the study, where data from two districts were compared, we cannot identify any systematic bias in selfreporting between the two districts that may have significantly influenced the comparison and thus the interpretation of the study.

\section{Materials and Methods}

\subsection{Site Selection}

Uganda is a low-income country in East Africa (see Figure 1) with a population of about 47 million people in 2021 [39]. Of all households, in 2014 almost 80\% were engaged in agriculture and $69 \%$ had subsistence farming as their main income source, although this varied considerably between rural and urban areas ( $82 \%$ versus $29 \%$ of households) [40]. On the other hand, only $2 \%$ of households had commercial farming as their main income source. The number of agricultural households that kept pigs in 2018 was 1,345,000, with an average of four pigs per farm [41]. The pig population in Uganda is on the rise, with a total of 4.5 million pigs in 2018.

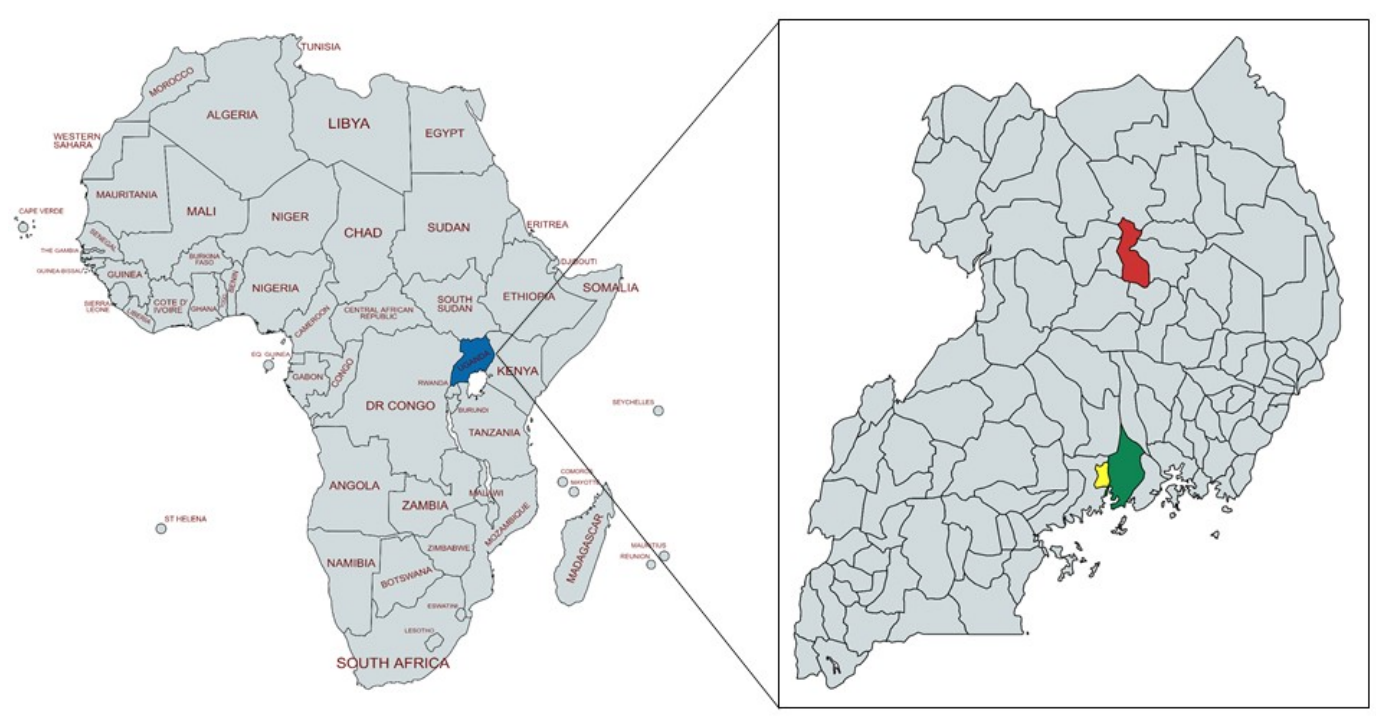

Figure 1. Map of the continent of Africa with Uganda marked in blue (left). Map of Uganda with the surveyed districts marked in red (Lira) and green (Mukono), as well as Kampala district marked in yellow (right). Source: https://mapchart.net, accessed on 2 December 2021, license: https:/ / creativecommons.org/licenses/by-sa/4.0/ accessed on 2 December 2021.

The current study was conducted in Mukono and Lira districts in Uganda (see Figure 1). Mukono district is in central Uganda at $40 \mathrm{~km}$ from Kampala, the capital of Uganda, with a human population in 2014 of 596,804 people [40]. In $2008,63 \%$ of all households kept some kind of livestock and 23\% kept pigs [42]. The same year, Mukono was one of the districts with the highest number of pigs in the country. Because of the proximity to Kampala, livestock farmers are assumed to have good access to veterinary drugs and animal health services.

Lira district is in Northern Uganda, about $300 \mathrm{~km}$ from Kampala with a population of 408,043 in 2014 [40]. In 2008, 80\% of all households in the district were engaged in livestock 
rearing [42] and crop farming and livestock keeping are two main contributors to people's livelihoods [43]. In 2008, only about 7\% of all households kept pigs [42], but pig farming has increasingly become an important enterprise and many people rely on this as their main income source and use the animals as financial assets to pay for school fees and other expenses [43].

\subsection{Sample Size}

The sample size of 240 farms in Lira and 242 in Mukono allowed the detection of a difference between the populations of 0.13 when one of the proportions is 0.5 , or 0.1 if one of the proportions is 0.1 or 0.9 , at a significance level of 0.05 and with a power of 0.8 (https:/ / epitools.ausvet.com.au/twoproportions, accessed on 20 December 2021).

\subsection{Farmer Selection}

The target population of the study was pig farmers (male and female) in Lira and Mukono districts. District Veterinary Officers (DVO) from both districts were informed prior to the study to identify the top four sub-counties with the highest pig population density to serve as a sampling frame. In each sub-county, two villages were randomly selected for the study, making a total of eight villages per district and 16 villages in total. From each village, 30 farmers were randomly selected to be enrolled in the study. This resulted in a total sample of 240 farmers from Lira and 242 from Mukono.

\subsection{Drug Profiling}

Prior to the farm survey, the investigating team carried out a profiling of all drugs stored in retail shops in urban and peri-urban areas of the respective districts, using a drug profiling tool that has been previously presented [44]. Charts of common drugs were created to facilitate recall of drugs used by farmers during the interview. For farmers who could not recall the drugs they had used in the past months, the drug cards were shown to help them remember.

\subsection{Data Collection}

\subsubsection{Questionnaire}

The questionnaire used in the study was based on the 'Antimicrobial use in livestock production systems' (AMUSE Livestock tool) developed by a working group from the CGIAR Research Program on Livestock (see supplementary material File S2). The questionnaire was developed to facilitate harmonized data collection regarding farmer knowledge, attitudes and practices within the AMR conceptual framework in LMICs, and modified versions of the questionnaire have been used in other African countries, such as Ethiopia [45].

The AMUSE tool comprises 75 questions covering (1) Farm basics and location, (2) Household demographics, (3) Farm characteristics, (4) Management of manure, feed and water, (5) Animal health and disease prevention, (6) Animal health services, (7) Veterinary drug use, and (8) Use of antibiotics. Also, questions about the respondent's knowledge about the effects of vaccines and antibiotics are included.

\subsubsection{Questionnaire Administration}

The questionnaire was administered between 13 August and 10 September 2018 and was recorded electronically on tablets using Open Data Kit (ODK) [46], an open-source tool for smart devices (i.e., smartphone or tablet) that enables creation and use of electronic questionnaires. The data collection through ODK was backed up daily.

\subsubsection{Training of Enumerators}

The field work was led by a research technician who is a veterinarian. In total, eight enumerators were hired for this work. One enumerator was allocated to one sub-country, hence covering two villages. Enumerators were trained on data collection to make sure the 
interpretations and translations were properly performed and that the use of ODK on the tablets was correct. The questionnaire was then tested by each enumerator on three to five farmers each to make sure that whole data entry procedures worked.

\subsection{Data Processing and Analysis}

Since being a pig farmer was a selection criterion, 17 farms were removed from the dataset after the respondents at these farms stated that they had zero pigs. The selection criterion for the respondent was that the person should play a major role in the management of livestock. Therefore, additionally, two farms were removed as the respondents said that they had no relation to the livestock at the farm. The respondents that did not answer "Management" to the question about their role in relation to livestock answered "Owner" instead (eight in Lira and 17 in Mukono) and were therefore considered enough involved to be kept in the dataset. After the two removals, there were 463 farms left in the dataset, 229 in Lira and 234 in Mukono. In addition, inconsistent, or contradictory, answers were removed.

The processing and the statistical analyses of the data were performed after import to STATA. The two-sample test of proportions was used to compare the two districts regarding categorical data where proportions and samples were large enough to fulfil the assumptions $\left(n_{S} \cdot \hat{p_{0}}>10, n_{S} \cdot\left(1-\hat{p_{0}}\right)>10, n_{N} \cdot \hat{p_{0}}>10\right.$ and $n_{N} \cdot\left(1-\hat{p_{0}}\right)>10$ where $n_{N}$ and $n_{S}=$ sample sizes of the two districts, $p_{N}$ and $p_{S}=$ proportions in the two districts and $\left.\hat{p_{0}}=\left(n_{S} \cdot \hat{p_{S}}+n_{N} \cdot \hat{p_{N}}\right) /\left(n_{N}+n_{S}\right)\right)$. In the cases that the assumptions were not fulfilled, no statistical tests were performed and " $\mathrm{n} / \mathrm{a}$ " (not applicable) is noted in the $p$-value column. Mean values were compared using the two-sample $t$-test with equal variances. Both test types were conducted with a significance level of $95 \%$.

\section{Conclusions}

Our findings suggest that knowledge and practices regarding antibiotic resistance and use are not uniform within the same national legal framework but are associated with geographic settings and socioeconomic circumstances. Likely, this variability is larger in countries where the governmental resources to enforce regulations is limited. This in turn calls for AMR-reducing interventions that are tailored for the specific context in which they are to be implemented as a complement to national regulations. To be able to accomplish this tailoring, a systematic collection of knowledge of farm structures, farm practices and access to animal health services and veterinary drugs is necessary.

Supplementary Materials: The following supporting information can be downloaded at: https:/ / www.mdpi.com/article/10.3390/antibiotics11020251/s1, Table S1: Demographics and socioeconomic characteristics, Table S2: Farm charactersistics, Table S3: Feeding and manure management routines, Table S4: Disease occurrence, Supplementary material File S2: AMUSE questionnaire.

Author Contributions: Conceptualization, B.W., U.M.; methodology, M.M.D., B.W., U.M.; validation, M.M.D., S.N.; formal analysis, S.N., U.M.; investigation, A.C.W., L.O., M.M.D.; resources, M.M.D., B.W., U.M.; data curation, S.N.; writing-original draft preparation, S.N.; writing-review and editing, S.N., M.M.D., B.W., U.M.; visualization, S.N.; supervision, M.M.D., B.W., U.M.; project administration, M.M.D., B.W., U.M.; funding acquisition, B.W., U.M. All authors have read and agreed to the published version of the manuscript.

Funding: The work was financially supported by the CGIAR Trust Fund via the CGIAR Research Program on Livestock.

Institutional Review Board Statement: The study was conducted according to the guidelines of the Declaration of Helsinki, and approved by the Institutional Ethical Review Committee of the College of Veterinary Medicine, Animal Resources and Biosecurity of Makerere University, Uganda (Ref: SBLS.MD.2017), and from the Uganda National Council for Science and Technology (ref: A 583 of 18 June 2018).

Informed Consent Statement: Informed consent was obtained from all respondents that participated in the study. 
Data Availability Statement: The data has been submitted to the SND public repository at https: / / hdl.handle.net/20.500.12703/3942 accessed on 2 December 2021.

Acknowledgments: The authors acknowledge the skilled enumerators collecting data in the field and the interviewed farmers that generously shared their insight with us.

Conflicts of Interest: The authors declare no conflict of interest. The funders had no role in the design of the study; in the collection, analyses, or interpretation of data; in the writing of the manuscript, or in the decision to publish the results.

\section{References}

1. Rushton, J.; Ferreira, J.P.; Stärk, K. Antimicrobial Resistance: The Use of Antimicrobials in the Livestock Sector. In OECD Food, Agriculture and Fisheries Papers; OECD Publishing: Paris, France, 2014. [CrossRef]

2. O'Neill, J. Antimicrobial Resistance: Tackling a Crisis for the Health and Wealth of Nations. Review on Antimicrobial Resistance. 2014. Available online: https:/ / wellcomecollection.org/works/rdpck35v (accessed on 11 February 2022).

3. World Bank. Drug-Resistant Infections: A Threat to Our Economic Future; World Bank: Washington, DC, USA, 2017. Available online: https:/ / openknowledge.worldbank.org/handle/10986/26707 (accessed on 11 February 2022).

4. Aminov, R.I. The role of antibiotics and antibiotic resistance in nature. Environ. Microbiol. 2009, 11, 2970-2988. [CrossRef] [PubMed]

5. Martinez, J.L. General principles of antibiotic resistance in bacteria. Drug Discov. Today Technol. 2014, 11, 33-39. [CrossRef] [PubMed]

6. Holmes, A.H.; Moore, L.S.; Sundsfjord, A.; Steinbakk, M.; Regmi, S.; Karkey, A.; Guerin, P.J.; Piddock, L.J. Understanding the mechanisms and drivers of antimicrobial resistance. Lancet 2016, 387, 176-187. [CrossRef]

7. GLASS. Global Antimicrobial Resistance and Use Surveillance System (GLASS) Report 2021; World Health Organization: Geneva, Switzerland, 2021; ISBN 978-92-4-002733-6.

8. Van Boeckel, T.P.; Brower, C.; Gilbert, M.; Grenfell, B.T.; Levin, S.A.; Robinson, T.P.; Teillant, A.; Laxminarayan, R. Global trends in antimicrobial use in food animals. Proc. Natl. Acad. Sci. USA 2015, 112, 5649-5654. [CrossRef] [PubMed]

9. European Centre for Disease Prevention and Control (ECDC); European Food Safety Authority (EFSA); European Medicines Agency (EMA). ECDC/EFSA/EMA First Joint Report on the Integrated Analysis of the Consumption of Antimicrobial Agents and Occurrence of Antimicrobial Resistance in Bacteria from Humans and Food-Producing Animals. EFSA J. 2015, 13, 4006. [CrossRef]

10. Van Boeckel, T.P.; Pires, J.; Silvester, R.; Zhao, C.; Song, J.; Criscuolo, N.G.; Gilbert, M.; Bonhoeffer, S.; Laxminarayan, R. Global trends in antimicrobial resistance in animals in low- and middle-income countries. Science 2019, 365, eaaw1944. [CrossRef]

11. Aarestrup, F.M.; Wegener, H.C.; Collignon, P. Resistance in bacteria of the food chain: Epidemiology and control strategies. Expert Rev. Anti Infect. Ther. 2008, 6, 733-750. [CrossRef]

12. Robinson, T.P.; Bu, D.P.; Carrique-Mas, J.; Fèvre, E.M.; Gilbert, M.; Grace, D.; Hay, S.I.; Jiwakanon, J.; Kakkar, M.; Kariuki, S.; et al. Antibiotic resistance is the quintessential One Health issue. Trans. R. Soc. Trop. Med. Hyg. 2016, 110, 377-380. [CrossRef]

13. UNAS; CDDEP; GARP-Uganda; Mpairwe, Y.; Wamala, S. Antibiotic Resistance in Uganda: Situation Analysis and Recommendations; Uganda National Academy of Sciences: Kampala, Uganda; Center for Disease Dynamics, Economics \& Policy: Washington, DC, USA, 2015; ISBN 978-9970-424-10-8.

14. Pham-Duc, P.; Cook, M.A.; Cong-Hong, H.; Nguyen-Thuy, H.; Padungtod, P.; Nguyen-Thi, H.; Dang-Xuan, S. Knowledge, attitudes and practices of livestock and aquaculture producers regarding antimicrobial use and resistance in Vietnam. PLoS ONE 2019, 14, e0223115. [CrossRef]

15. Caudell, M.A.; Dorado-Garcia, A.; Eckford, S.; Creese, C.; Byarugaba, D.K.; Afakye, K.; Chansa-Kabali, T.; Fasina, F.O.; Kabali, E.; Kiambi, S.; et al. Towards a bottom-up understanding of antimicrobial use and resistance on the farm: A knowledge, attitudes, and practices survey across livestock systems in five African countries. PLoS ONE 2020, 15, e0220274. [CrossRef]

16. Kateete, D.P.; Namazzi, S.; Okee, M.; Okeng, A.; Baluku, H.; Musisi, N.L.; Katabazi, F.A.; Joloba, M.L.; Ssentongo, R.; Najjuka, F.C. High prevalence of methicillin resistant Staphylococcus aureus in the surgical units of Mulago hospital in Kampala, Uganda. BMC Res. Notes 2011, 4, 326. [CrossRef] [PubMed]

17. Kateete, D.P.; Kabugo, U.; Baluku, H.; Nyakarahuka, L.; Kyobe, S.; Okee, M.; Najjuka, C.F.; Joloba, M.L. Prevalence and antimicrobial susceptibility patterns of bacteria from milkmen and cows with clinical mastitis in and around Kampala, Uganda. PLOS ONE 2013, 8, e63413. [CrossRef]

18. Ikwap, K.; Erume, J.; Owiny, D.O.; Nasinyama, G.W.; Melin, L.; Bengtsson, B.; Lundeheim, N.; Fellström, C.; Jacobson, M. Salmonella species in piglets and weaners from Uganda: Prevalence, antimicrobial resistance and herd-level risk factors. Prev. Vet. Med. 2014, 115, 39-47. [CrossRef] [PubMed]

19. Ikwap, K.; Gertzell, E.; Hansson, I.; Dahlin, L.; Selling, K.; Magnusson, U.; Dione, M.; Jacobson, M. The presence of antibioticresistant Staphylococcus spp. and Escherichia coli in smallholder pig farms in Uganda. BMC Vet. Res. 2021, 17, 31. [CrossRef] [PubMed] 
20. Kateregga, J.N.; Kantume, R.; Atuhaire, C.; Lubowa, M.N.; Ndukui, J.G. Phenotypic expression and prevalence of ESBL-producing Enterobacteriaceae in samples collected from patients in various wards of Mulago Hospital, Uganda. BMC Pharmacol. Toxicol. 2015, 16, 14. [CrossRef]

21. Okello, E.; Moonens, K.; Erume, J.; De Greve, H. Enterotoxigenic Escherichia coli strains are highly prevalent in Ugandan piggeries but disease outbreaks are masked by antibiotic prophylaxis. Trop. Anim. Health Prod. 2015, 47, 117-122. [CrossRef]

22. Okubo, T.; Yossapol, M.; Maruyama, F.; Wampande, E.M.; Kakooza, S.; Ohya, K.; Tsuchida, S.; Asai, T.; Kabasa, J.D.; Ushida, K. Phenotypic and genotypic analyses of antimicrobial resistant bacteria in livestock in Uganda. Transbound. Emerg. Dis. 2019, 66, 317-326. [CrossRef]

23. Katakweba, A.A.S.; Muhairwa, A.P.; Lupindu, A.M.; Damborg, P.; Rosenkrantz, J.T.; Minga, U.M.; Mtambo, M.M.A.; Olsen, J.E. First Report on a Randomized Investigation of Antimicrobial Resistance in Fecal Indicator Bacteria from Livestock, Poultry, and Humans in Tanzania. Microb. Drug Resist. 2018, 24, 260-268. [CrossRef]

24. Subbiah, M.; Caudell, M.A.; Mair, C.; Davis, M.A.; Matthews, L.; Quinlan, R.J.; Quinlan, M.B.; Lyimo, B.; Buza, J.; Keyyu, J.; et al. Antimicrobial resistant enteric bacteria are widely distributed amongst people, animals and the environment in Tanzania. Nat. Commun. 2020, 11, 228. [CrossRef]

25. Kimera, Z.I.; Mgaya, F.X.; Misinzo, G.; Mshana, S.E.; Moremi, N.; Matee, M.I.N. Multidrug-Resistant, Including ExtendedSpectrum Beta Lactamase-Producing and Quinolone-Resistant, Escherichia coli Isolated from Poultry and Domestic Pigs in Dar es Salaam, Tanzania. Antibiotics 2021, 10, 406. [CrossRef]

26. Magnusson, U. Prudent and effective antimicrobial use in a diverse livestock and consumer's world. J. Anim. Sci. 2020, 98, S4-S8. [CrossRef] [PubMed]

27. Robinson, T.P.; Bu, D.P.; Carrique-Mas, J.; Fèvre, E.M.; Gilbert, M.; Grace, D.; Hay, S.I.; Jiwakanon, J.; Kakkar, M.; Kariuki, S.; et al. Antibiotic resistance: Mitigation opportunities in livestock sector development. Animal 2017, 11, 1-3. [CrossRef] [PubMed]

28. Zellweger, R.M.; Carrique-Mas, J.; Limmathurotsakul, D.; Day, N.P.J.; Thwaites, G.E.; Baker, S. A current perspective on antimicrobial resistance in Southeast Asia. J. Antimicrob. Chemother. 2017, 72, 2963-2972. [CrossRef] [PubMed]

29. Dione, M.M.; Ouma, E.A.; Roesel, K.; Kungu, J.; Lule, P.; Pezo, D. Participatory assessment of animal health and husbandry practices in smallholder pig production systems in three high poverty districts in Uganda. Prev. Vet. Med. 2014, 117, 565-576. [CrossRef]

30. Chenais, E.; Boqvist, S.; Sternberg-Lewerin, S.; Emanuelson, U.; Ouma, E.; Dione, M.; Aliro, T.; Crafoord, F.; Masembe, C.; Ståhl, K. Knowledge, Attitudes and Practices Related to African Swine Fever Within Smallholder Pig Production in Northern Uganda. Transbound. Emerg. Dis. 2017, 64, 101-115. [CrossRef]

31. Checcucci, A.; Trevisi, P.; Luise, D.; Modesto, M.; Blasioli, S.; Braschi, I.; Mattarelli, P. Exploring the Animal Waste Resistome: The Spread of Antimicrobial Resistance Genes Through the Use of Livestock Manure. Front. Microbiol. 2020, 11, 1416. [CrossRef]

32. Marti, R.; Scott, A.; Tien, Y.C.; Murray, R.; Sabourin, L.; Zhang, Y.; Topp, E. Impact of manure fertilization on the abundance of antibiotic-resistant bacteria and frequency of detection of antibiotic resistance genes in soil and on vegetables at harvest. Appl. Environ. Microbiol. 2013, 79, 5701-5709. [CrossRef]

33. Ndambi, O.A.; Pelster, D.E.; Owino, J.O.; de Buisonjé, F.; Vellinga, T. Manure Management Practices and Policies in Sub-Saharan Africa: Implications on Manure Quality as a Fertilizer. Front. Sustain. Food Syst. 2019, 3, 29. [CrossRef]

34. Rufino, M.C.; Rowe, E.C.; Delve, R.J.; Giller, K.E. Nitrogen cycling efficiencies through resource-poor African crop-livestock systems. Agric. Ecosyst. Environ. 2006, 112, 261-282. [CrossRef]

35. Dione, M.M.; Amia, W.C.; Ejobi, F.; Ouma, E.A.; Wieland, B. Supply Chain and Delivery of Antimicrobial Drugs in Smallholder Livestock Production Systems in Uganda. Front. Vet. Sci. 2021, 8, 611076. [CrossRef]

36. Barbosa, T.M.; Levy, S.B. The impact of antibiotic use on resistance development and persistence. Drug Resist. Updates 2000, 3 , 303-311. [CrossRef] [PubMed]

37. FAO. Drivers, Dynamics and Epidemiology of Antimicrobial Resistance in Animal Production; Food and Agriculture Organization of the United Nations: Rome, Italy, 2016; ISBN 978-92-5-109441-9.

38. Magnusson, U.; Moodley, A.; Osbjer, K. Antimicrobial resistance at the livestock-human interface: Implications for Veterinary Services. Rev. Sci. Tech. 2021, 40, 511-521. [CrossRef] [PubMed]

39. United Nations Population Fund (UNFPA) Website. World Population Dashboard, Uganda. Available online: https://www. unfpa.org/data/world-population/UG (accessed on 22 June 2021).

40. Uganda Bureau of Statistics (UBOS). The National Population and Housing Census 2014-Main Report; Uganda Bureau of Statistics: Kampala, Uganda, 2016.

41. Uganda Bureau of Statistics (UBOS). Uganda Annual Agricultural Survey 2018; Uganda Bureau of Statistics: Kampala, Uganda, 2020.

42. Uganda Bureau of Statistics (UBOS); Ministry of Agriculture, Animal Industry and Fisheries (MAAIF). The National Livestock Census Report 2008; UBOS: Kampala, Uganda; MAAIF: Entebbe, Uganda, 2009.

43. Ouma, E.A.; Dione, M. Uganda Smallholder Pig Value Chain Site Scoping Report: Lira, Kibaale and Hoima Districts; International Livestock Research Institute (ILRI): Nairobi, Kenya, 2014. Available online: https://cgspace.cgiar.org/bitstream/handle/10568/ 45980/more_pork_site_scoping_aug_2014.pdf?sequence=1 (accessed on 11 February 2022). 
44. Dione, M.; Amia, W.C.; Wieland, B. Assessment of Antimicrobial Use and Management in Livestock Systems: Tool for Assessing the Knowledge, Attitudes and Practices (KAP) of Veterinary Drug Inputs Suppliers about Antimicrobial Use in Livestock Production Systems; International Livestock Research Institute (ILRI): Nairobi, Kenya, 2020.

45. Gemeda, B.A.; Amenu, K.; Magnusson, U.; Dohoo, I.; Hallenberg, G.S.; Alemayehu, G.; Desta, H.; Wieland, B. Antimicrobial Use in Extensive Smallholder Livestock Farming Systems in Ethiopia: Knowledge, Attitudes, and Practices of Livestock Keepers. Front. Vet. Sci. 2020, 7, 55. [CrossRef] [PubMed]

46. Open Data Kit (ODK) Website. Available online: https://getodk.org (accessed on 8 December 2021). 